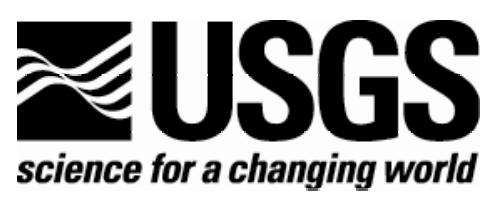

\title{
Major crustal fault zone trends and their relation to mineral belts in the north-central Great Basin, Nevada
}

By Brian D. Rodriguez, Jay A. Sampson, and Jackie M. Williams

Open-File Report 2007-1115

U.S. DEPARTMENT OF THE INTERIOR U.S. GEOLOGICAL SURVEY 


\section{U.S. Department of the Interior DIRK KEMPTHORNE, Secretary}

\section{U.S. Geological Survey Mark D. Myers, Director}

\section{U.S. Geological Survey, Reston, Virginia 2007}

For product and ordering information:

World Wide Web: http://www.usgs.gov/pubprod

Telephone: 1-888-ASK-USGS

For more information on the USGS - the Federal source for science about the Earth, its natural and living resources, natural hazards, and the environment:

World Wide Web: http://www.usgs.gov

Telephone: 1-888-ASK-USGS

Suggested citation:

Rodriguez, B.D., Sampson, J.A., and Williams, J.M., 2007, Major crustal fault zone trends and their relation to mineral belts in the north-central Great Basin, Nevada: U.S. Geological Survey Open-File Report 2007-1115, 17 p.

Any use of trade, product, or firm names is for descriptive purposes only and does not imply endorsement by the U.S. Government.

Although this report is in the public domain, permission must be secured from the individual copyright owners to reproduce any copyrighted material contained within this report. 


\section{Contents}

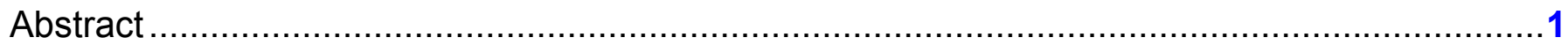

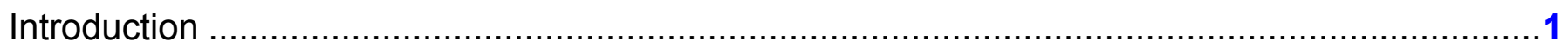

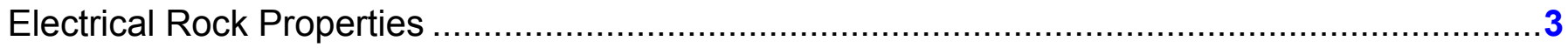

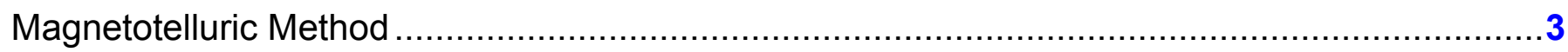

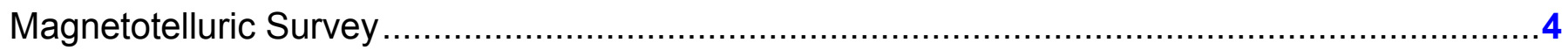

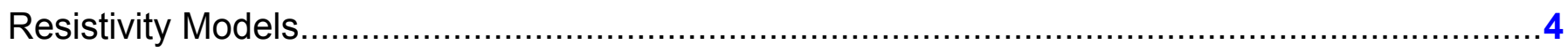

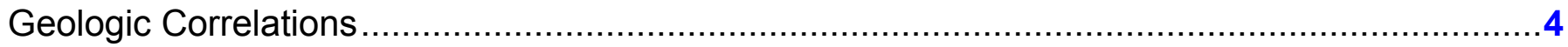

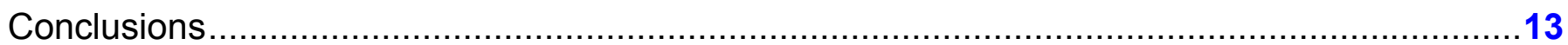

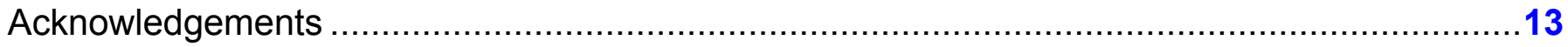

References Cited

\section{Figures}

1. Index image of northern Nevada showing magnetotelluric profiles MT1 to MT9 ............2

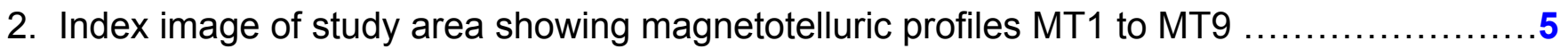

3. Two-dimensional resistivity models of magnetotelluric profiles MT1 to MT4 .................6

4. Two-dimensional resistivity models of magnetotelluric profiles MT5 to MT9 ….............

5. Deep conductor, electrical-strike directions for magnetotelluric profiles MT1 to MT9 ........9

6. Shallow conductor, electrical-strike directions for magnetotelluric profiles MT1 to MT9.....11

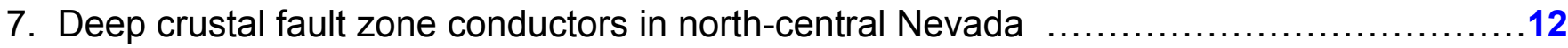




\section{Abstract}

The Great Basin physiographic province covers a large part of the western United States and contains one of the world's leading gold-producing areas, the Carlin Trend. In the Great Basin, many sedimentary-rock-hosted disseminated gold deposits occur along such linear mineral-occurrence trends. The distribution and genesis of these deposits is not fully understood, but most models indicate that regional tectonic structures play an important role in their spatial distribution. Over 100 magnetotelluric (MT) soundings were acquired between 1994 and 2001 by the U.S. Geological Survey to investigate crustal structures that may underlie the linear trends in north-central Nevada. MT sounding data were used to map changes in electrical resistivity as a function of depth that are related to subsurface lithologic and structural variations. Two-dimensional (2-D) resistivity modeling of the MT data reveals primarily northerly and northeasterly trending narrow 2-D conductors (1 to $30 \mathrm{ohm}-\mathrm{m}$ ) extending to mid-crustal depths $(5-20 \mathrm{~km})$ that are interpreted to be major crustal fault zones. There are also a few westerly and northwesterly trending 2-D conductors. However, the great majority of the inferred crustal fault zones mapped using MT are perpendicular or oblique to the generally accepted trends. The correlation of strike of three crustal fault zones with the strike of the Carlin and Getchell trends and the Alligator Ridge district suggests they may have been the root fluid flow pathways that fed faults and fracture networks at shallower levels where gold precipitated in favorable host rocks. The abundant northeasterly crustal structures that do not correlate with the major trends may be structures that are open to fluid flow at the present time.

\section{Introduction}

Many sedimentary-rock-hosted disseminated gold deposits occur along linear mineral-occurrence trends in northern Nevada (Struhsacker and others, 1996). The distribution and genesis of these deposits along the Battle Mountain-Eureka (BME) and Carlin trends is not fully understood. In general, most geologic models suggest that regional structures played an important role in the spatial distribution of these deposits (e.g. Arehart and others, 1993; Ilchik and Barton, 1997; Radtke, 1985; Shawe, 1991; Sillitoe and Bonham, 1990; Tosdal and others, 2000). To investigate crustal structures that may underlie these trends, nine profiles of magnetotelluric (MT) soundings were acquired between 1994 and 2001 (lines MT1 to MT9, fig. 1). Modeling of the MT data can be used to infer the deep resistivity structure of the crust. Such structures may reflect possible tectonic controls on the emplacement of mineral deposits along these linear trends, and so may be used to help improve critical gold endowment estimates in the north-central Great Basin.

The attributes and location of major faults within the Northern Nevada Gold Province are relevant to crustal development and ore deposit models (Hofstra and Cline, 2000; Grauch and others, 2003). To better constrain the location and strike of major faults below cover, nine regional magnetotelluric (MT) sounding profiles were acquired in north-central Nevada (Williams and Rodriguez, 2000; 2001a; 2001b; 2001c; 2001d; Williams, and others, 2001a; 2001b; 2001c). 


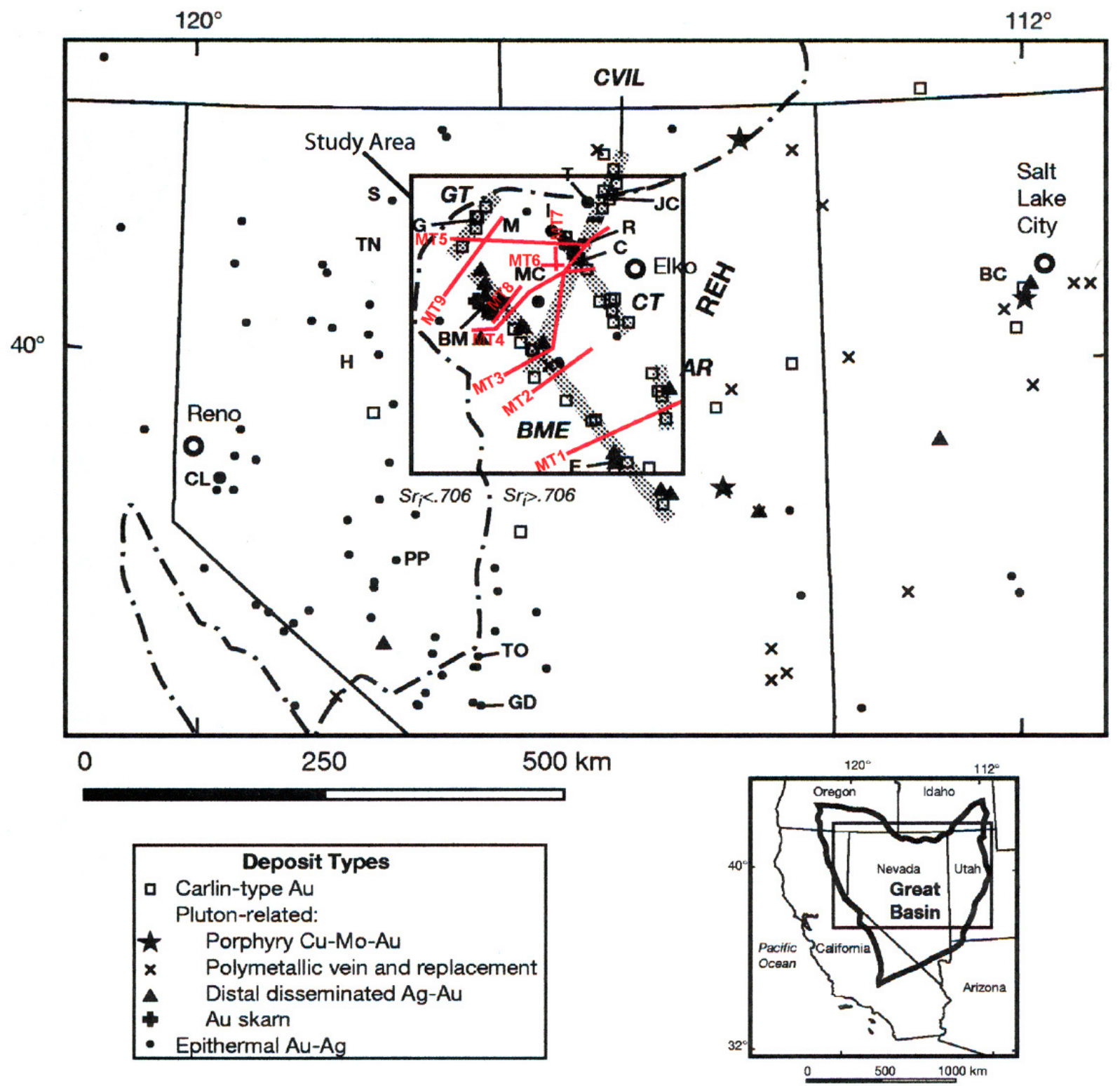

Figure 1. Index image of northern Nevada showing magnetotelluric (MT) profiles, MT1 to MT9 (red line segments) modified from John and others (2003). Wide dotted lines show the major mineral trends and lineaments. Black outlined box in main image shows the study area (fig. 2). Dot-dash line shows the initial ${ }^{87} \mathrm{Sr} /{ }^{86} \mathrm{Sr}=0.706$ isopleth (Sri) for the inferred edge of continental crust. Inset map shows the location of figure (box) and the outline of the Great Basin (heavy black line). AR = Alligator Ridge district; $B C=$ Barneys Canyon deposit; BM = Battle Mountain district; BME = Battle Mountain-Eureka trend; $\mathrm{C}=$ Carlin mine; $\mathrm{CL}=$ Comstock lode; $\mathrm{CT}=$ Carlin trend; $\mathrm{CVIL}=$ Crescent Valley-Independence lineament; $\mathrm{E}=$ Eureka district; $\mathrm{G}=$ Getchell mine; $\mathrm{GD}=$ Goldfield deposit; GT = Getchell trend; H = Humboldt Range; I = Ivanhoe deposit; JC = Jerritt Canyon district; $\mathrm{M}=$ Midas deposit; $\mathrm{MC}=$ Mule Canyon deposit; $\mathrm{PP}=$ Paradise Peak deposit; $\mathrm{S}=$ Sleeper deposit; $\mathrm{R}=$ Rodeo deposit; REH = Ruby-East Humboldt metamorphic core complex; $\mathrm{T}$ = Tuscarora district; $\mathrm{TN}=$ Tenmile district; $\mathrm{TO}=$ Tonopah district. 


\section{Electrical Rock Properties}

Electromagnetic (EM) geophysical methods detect variations in the electrical properties of rocks, in particular electrical resistivity or its inverse, electrical conductivity. Electrical resistivity can be correlated with geologic units on the surface and at depth using lithologic logs to provide a three-dimensional (3-D) picture of subsurface geology. The resistivity of geologic units in the upper crust is largely dependent upon their fluid content, pore-volume porosity, interconnected fracture porosity, and conductive mineral content (Keller, 1989). Fluid content and conductive mineral content dominate the resistivity response within the upper to middle crust, and undersaturated melting conditions may be dominant near the base of the crust. Fluids within the pore spaces and fracture openings, especially if saline, can reduce resistivities in what would otherwise be a resistive rock matrix. Resistivity can also be lowered by the content of electrically conductive clay minerals, graphitic carbon, and metallic mineralization. It is common for altered volcanic rocks to contain replacement minerals that have resistivities ten times lower than those of the surrounding rocks (Nelson and Anderson, 1992). Fine-grained sediments, such as clay-rich alluvium, marine shale, and other mudstones, are normally conductive from a few ohm-m to a few tens of ohm-m (Keller, 1987; Palacky, 1987). Deszcz-Pan and others (2000) report that coarser-grained sediments, such as gravels and clean sands, are commonly moderately conductive (tens of ohm-m). Metamorphic rocks (non-graphitic) and unaltered, unfractured igneous rocks are normally moderately to highly resistive (a few hundreds to thousands of ohm-m). Carbonate rocks can have similarly high resistivities depending on their fluid content, porosity, and impurities (Keller, 1987; Palacky, 1987). Fault zones may be moderately conductive (tens of ohm-m) when comprised of rocks fractured enough to have hosted fluid transport and consequent mineralogical alteration (Eberhart-Phillips and others, 1995) or when comprised of fractured rock that has graphitic enrichment along former shear planes (Ritter and others, 2005). Higher subsurface temperatures cause higher ionic mobility that reduces rock resistivities (Keller, 1987; Palacky, 1987). Tables of electrical resistivities for a variety of rocks, minerals, and geological environments may be found in Keller (1987) and Palacky (1987).

\section{Magnetotelluric Method}

The MT method is a passive surface EM geophysical technique that measures the Earth's natural electric and magnetic field to investigate the electrical resistivity structure of the subsurface from depths of tens of meters to tens of kilometers (Vozoff, 1991). Worldwide lightning activity at frequencies of $10,000 \mathrm{~Hz}$ to $1 \mathrm{~Hz}$ and geomagnetic micro-pulsations at frequencies of $1 \mathrm{~Hz}$ to $0.001 \mathrm{~Hz}$ provide the majority of signal used by the MT method. The natural electric and magnetic fields propagate vertically into the earth due to the very large resistivity contrast between the air and the earth, which causes a vertical refraction of both fields at the surface (Vozoff, 1972).

The natural electric and magnetic fields are recorded in two orthogonal, horizontal directions (the vertical magnetic field is also recorded). The resulting time-series signals are used to derive tensor apparent resistivities and phases by first converting them to complex cross spectra using Fourier transform techniques. Least squares, cross-spectral analysis (Bendat and Piersol, 1971) are used to solve for a tensor transfer function. For a two-dimensional (2-D) Earth, the MT fields can be decoupled into transverse-electric (TE) and transverse-magnetic (TM) modes; 2-D resistivity modeling is generally undertaken to fit both modes. When the geology satisfies the 2-D assumption, the MT data for the TE mode is assumed to represent the situation 
when the electric field is polarized along geologic strike, and the data for the TM mode when the electric field is oriented perpendicular to strike. The MT method is well suited for studying complicated geological environments because the electric and magnetic relations are sensitive to vertical and horizontal variations in resistivity. The method is capable of establishing whether the EM fields are responding to a 1-, 2-, or 3-dimensional subsurface. An introduction to the MT method and references for a more advanced understanding are contained in Dobrin and Savit (1988) and Vozoff (1991).

\section{Magnetotelluric Survey}

One-hundred and eleven MT soundings were located along nine profiles (MT1 to MT9, fig. 2) of lengths varying from 20 to $150 \mathrm{~km}$ and site spacing that varied laterally from 1.5 to $13.5 \mathrm{~km}$. The single station recordings for profiles MT1 to MT9 are reported in Williams and Rodriguez (2000; 2001a; 2001b; 2001c; 2001d) and Williams and others (2001a; 2001b; 2001c). In 2004, MT data with vertical magnetic field recordings at stations 130 and 131 (Williams and Rodriguez, 2005) were collected to resolve ambiguity in previously published MT data (stations $5 \mathrm{~A}$ and $6 \mathrm{~A}$ ) where electrical strike directions that vertical magnetic field recordings (Williams, and others, 2001a; 2001b).

\section{Resistivity Models}

The observed data used in the 2-D resistivity modeling (figs. 3 and 4) were rotated to maximum and minimum impedance directions so that propagation modes for the signals were decoupled into transverse electric (TE) and transverse magnetic (TM) modes (Williams and Rodriguez, 2000; 2001a; 2001b; 2001c; 2001d; Williams, and others, 2001a; 2001b; 2001c). Resistivity model construction and results are described in detail in Rodriguez and Williams (2001) for profiles MT1 to MT4 and in Rodriguez and Williams (2002) for profiles MT5 to MT9.

Forward modeling was achieved using Phil Wannamaker's 2-D finite-element integral solution program, PW2DIS (Wannamaker, 1989). We perturbed each 2-D model attempting to derive the best-fitting calculated response to the TE and TM mode observed data where the observed data indicated a 2-D response. However, we primarily attempted to fit the TM mode data where the observed data indicated a 3-D response (Wannamaker and others, 1984). Each 2-D resistivity model is constructed by adjusting the resistivity values beneath the profile of MT stations, so that for all stations the calculated 2-D response agrees with the measured data.

\section{Geologic Correlations}

In Rodriguez and Williams (2001; 2002), crustal high resistivity (300 to 1,000 ohm-m) was generally attributed to carbonates, intruded rock, plutonic rock, metamorphic rock, or Precambrian basement. Moderately resistive (30 to $300 \mathrm{ohm}-\mathrm{m}$ ) rocks were inferred to be volcanic and/or clastic sedimentary rocks. Evidence supporting these interpretations, such as exposures of Cretaceous quartz monzonite, Tertiary granodiorite, or widespread re-crystallized carbonates, and broad magnetic highs supporting the presence of large concealed plutons near MT stations, are reported in Rodriguez and Williams (2001; 2002). Narrow, sub-vertical, 2-D, low-resistivity (1 to $30 \mathrm{ohm}-\mathrm{m})$ conductors that penetrate to mid-crustal depths $(5-20 \mathrm{~km})$ are 


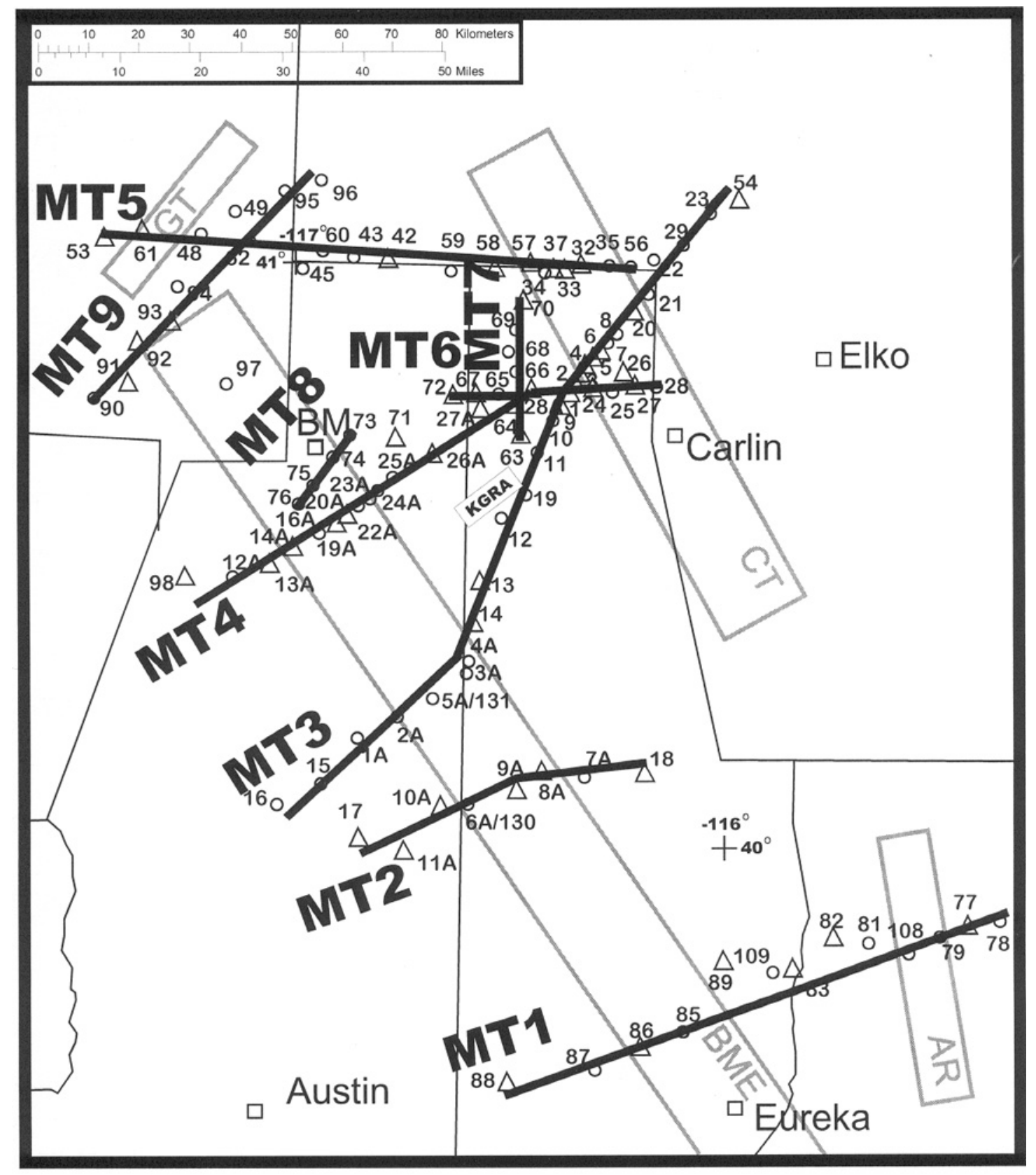

Figure 2. Index image of study area showing magnetotelluric (MT) profiles MT1 to MT9 (thick black lines), acquired from 1994 to 2000 in north-central Nevada (fig. 1). The gray lines represent generally accepted mineral belts in north-central Nevada (AR = Alligator Ridge district; $\mathrm{BME}=$ Battle Mountain-Eureka trend; $\mathrm{CT}=$ Carlin trend; $\mathrm{GT}=$ Getchell trend). Numbered MT stations are shown as open circles for MT data that are two-dimensional (2-D) in character and open triangles for data that have three-dimensional character in the lower frequencies. Thin black lines are county boundaries. KGRA is Beowawe Known Geothermal Resource Area. 


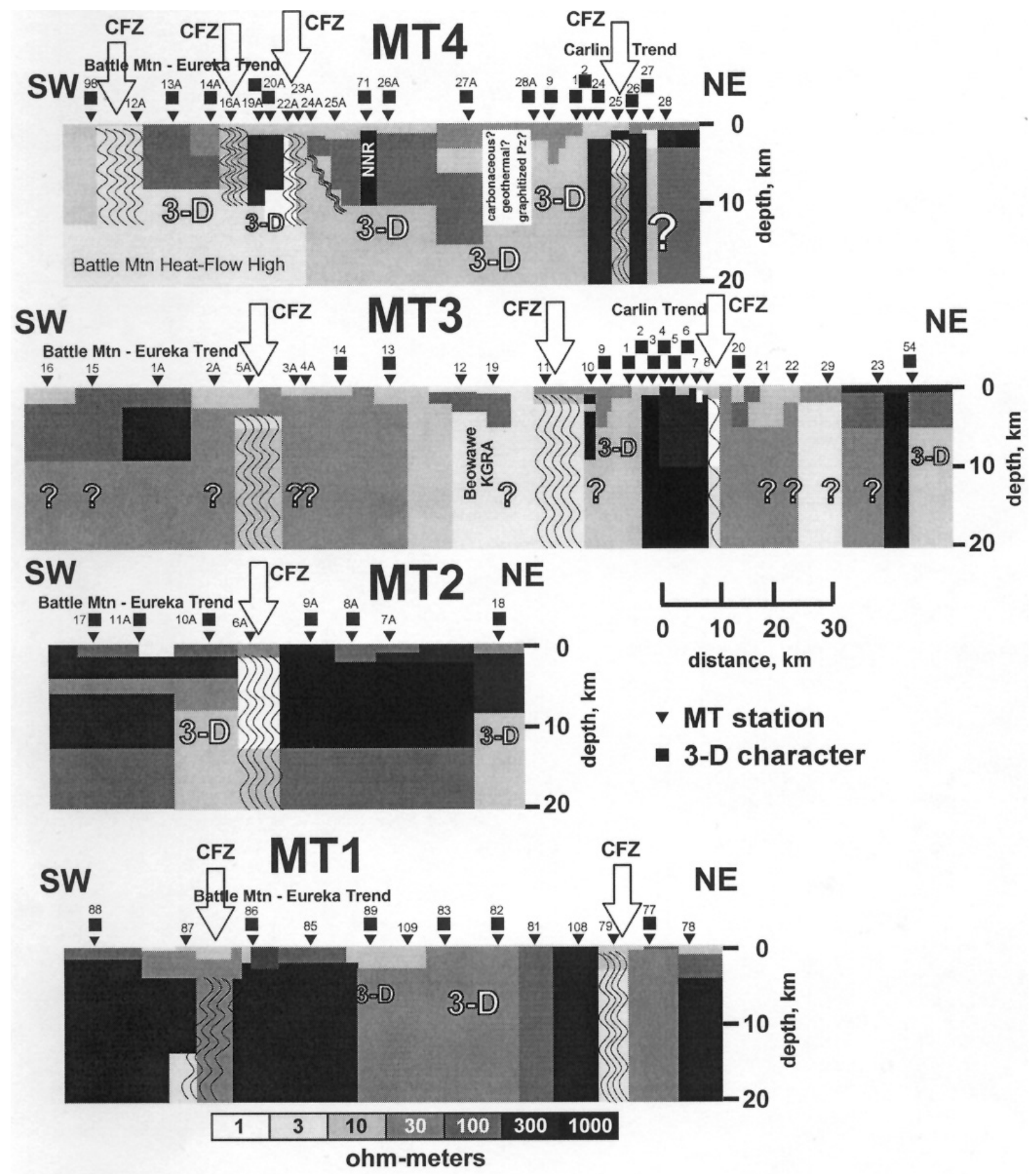

Figure 3. Two-dimensional resistivity models of magnetotelluric (MT) profiles MT1 to MT4. Depths are relative to ground surface. Black squares show stations whose MT data indicate three-dimensional character at lower frequencies. White arrows and serpentine black lines show deep model conductor that is inferred crustal fault zone (CFZ). Question marks indicate less certain model definition due to poor data quality. NNR is Northern Nevada Rift. Pz is Paleozoic rocks. Vertical exaggeration is 1.33:1, and physiographic locations are as in figure 2. 


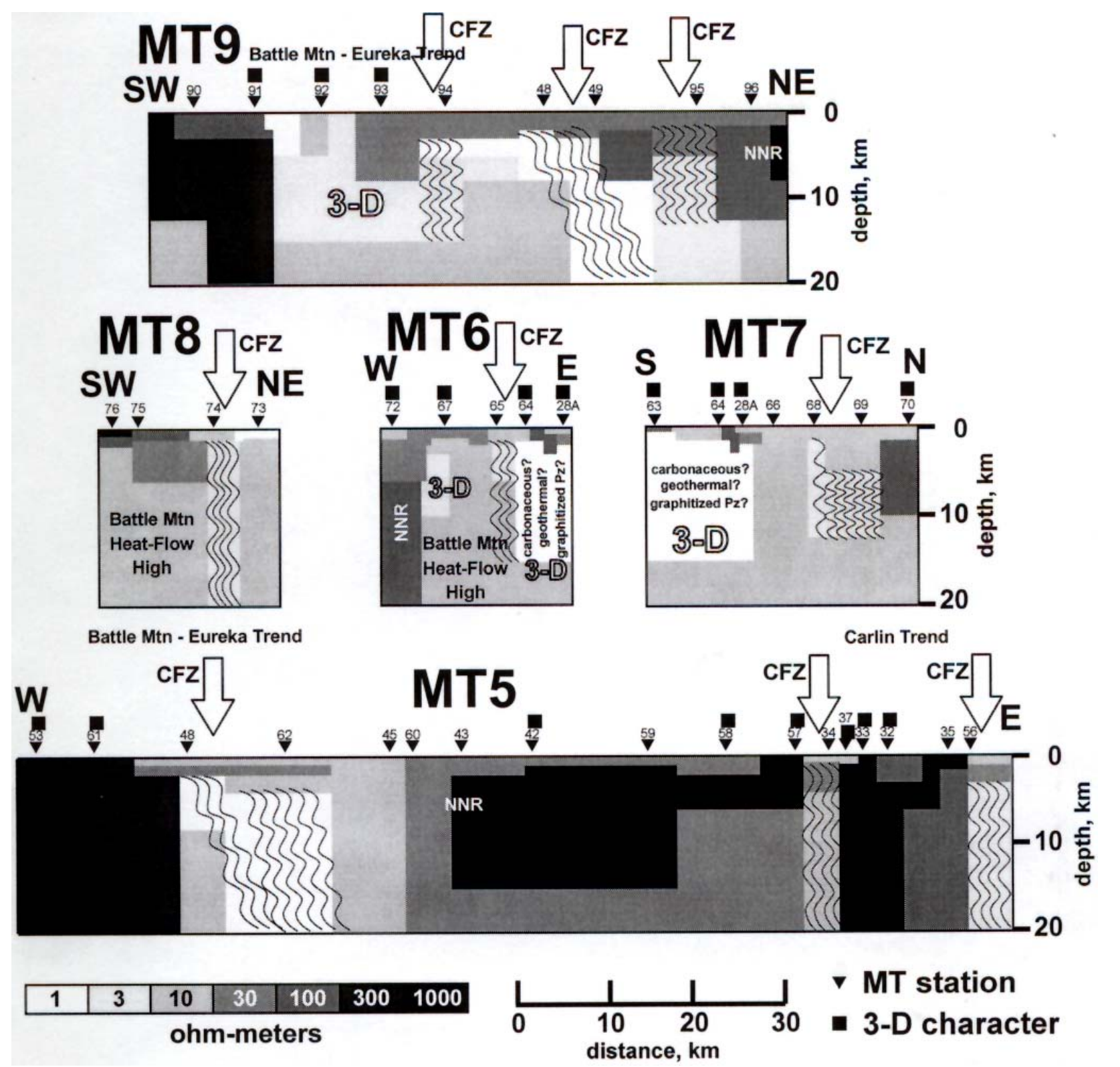

Figure 4. Two-dimensional resistivity models at no vertical exaggeration of magnetotelluric (MT) profiles MT5 to MT9. Depths are relative to ground surface. Black squares show stations whose MT data indicate three-dimensional character at the lower frequencies. White arrows and serpentine black lines show deep model conductor that is inferred crustal fault zone (CFZ). NNR is Northern Nevada Rift. Pz is Paleozoic rocks. Physiographic locations are as in figure 2. 
best explained by major crustal-scale fault or fracture zones. The low resistivities can be caused by material associated with faulting or fracture filling, such as mylonitic breccia, brine-filled fractures, argillaceous alteration from hydrothermal fluids, substantial graphitic carbon associated with shearing, or fluid-deposited graphite derived from organic shales in the section (Wannamaker and others, 2002), or possibly some combination of these (Eberhart-Phillips and others, 1995). The width of the inferred crustal fault zones, in general, are not well constrained due to the combination of wide station spacing, the resolving power of diffusive EM, and the node spacing of the grid size used in the resistivity models $(0.5-2 \mathrm{~km})$. In the resistivity models (figs. 3 and 4), the overall range of widths at about $10 \mathrm{~km}$ depth varies from about 0.5 to $7 \mathrm{~km}$ (after adjusting for projection widths). The actual conductor widths could be much narrower, and the exact cause of these conductors is inferred, not known. Not all crustal conductors were interpreted to be crustal fault zones. For example, the conductor ( $3 \mathrm{ohm}-\mathrm{m})$ beneath stations 12 and 19 (profile MT3, fig. 3) correlates with a known geothermal resource area (Beowawe KGRA, fig. 2). Conductors that are 3-D in character are attributed to other causes. For example, a large 3-D conductor ( $1 \mathrm{ohm}-\mathrm{m}$ ) from 1 to $12 \mathrm{~km}$ depth between stations 27A and 28A (profile MT4, fig. 3) may also be from a geothermal system, a thick section of carbonaceous rocks, graphitized deep-water clastic Paleozoic rocks, or even some combination of these. Also, shallow 3-D conductors in the upper $2 \mathrm{~km}$ may be a combination of conductive (1 to $30 \mathrm{ohm}-\mathrm{m}$ ) basin fill resting on shaley basement units, such as Devonian Pilot or early Mississippian Chainman Formations that have similar resistivities depending on their hydrocarbon maturity (Wannamaker and others, 2002). Finally, conductors that are 3-D in character may be due to a change in conductor strike direction or an intersection with another conductor with a different strike direction.

Some of the narrow, sub-vertical, 2-D conductors mapped by the MT profiles that penetrate to mid-crustal depths $(5-20 \mathrm{~km})$ correlate reasonably well with the locations of the major trends, but most have preferred electrical strike directions that are at oblique angles to the trends (fig. 5). The majority of the narrow conductors have north and northeast strikes, but a few have west and northwest strikes. Previous investigations of crustal structures that may be related to the genesis of gold deposits along the northwest-striking Battle Mountain-Eureka (BME) and Carlin trends point to the strong gravity gradient along the BME trend (Grauch and others, 1995), and the inferred fault zones under both BME and Carlin gold trends based on variations in the isotope geochemistry of granitoid intrusions (Tosdal and others, 2000). In earlier reports (Rodriguez and Williams, 2001; 2002) we inferred a major northwest-trending crustal fault zone along the BME trend based on data from an older MT data acquisition system that did not have the vertical magnetic field needed to resolve the $90^{\circ}$ ambiguity in electrical strike directions inherent with principal impedance directions. In 2004, as part of a different survey (Williams and Rodriguez, 2005), key stations were reoccupied that had been previously used to define the major northwest-trending inferred crustal fault zone along the BME trend. After collecting the vertical magnetic field with the new MT system, it was clear that the wrong electrical strike direction (the $90^{\circ}$ ambiguity) had been chosen. Figure 5 shows both the crustal fault zone strike directions determined with the new MT system (shown with red arrows) and the older MT system (that have the $90^{\circ}$ ambiguity in principal impedance strike directions; shown with the double set of blue arrows). 


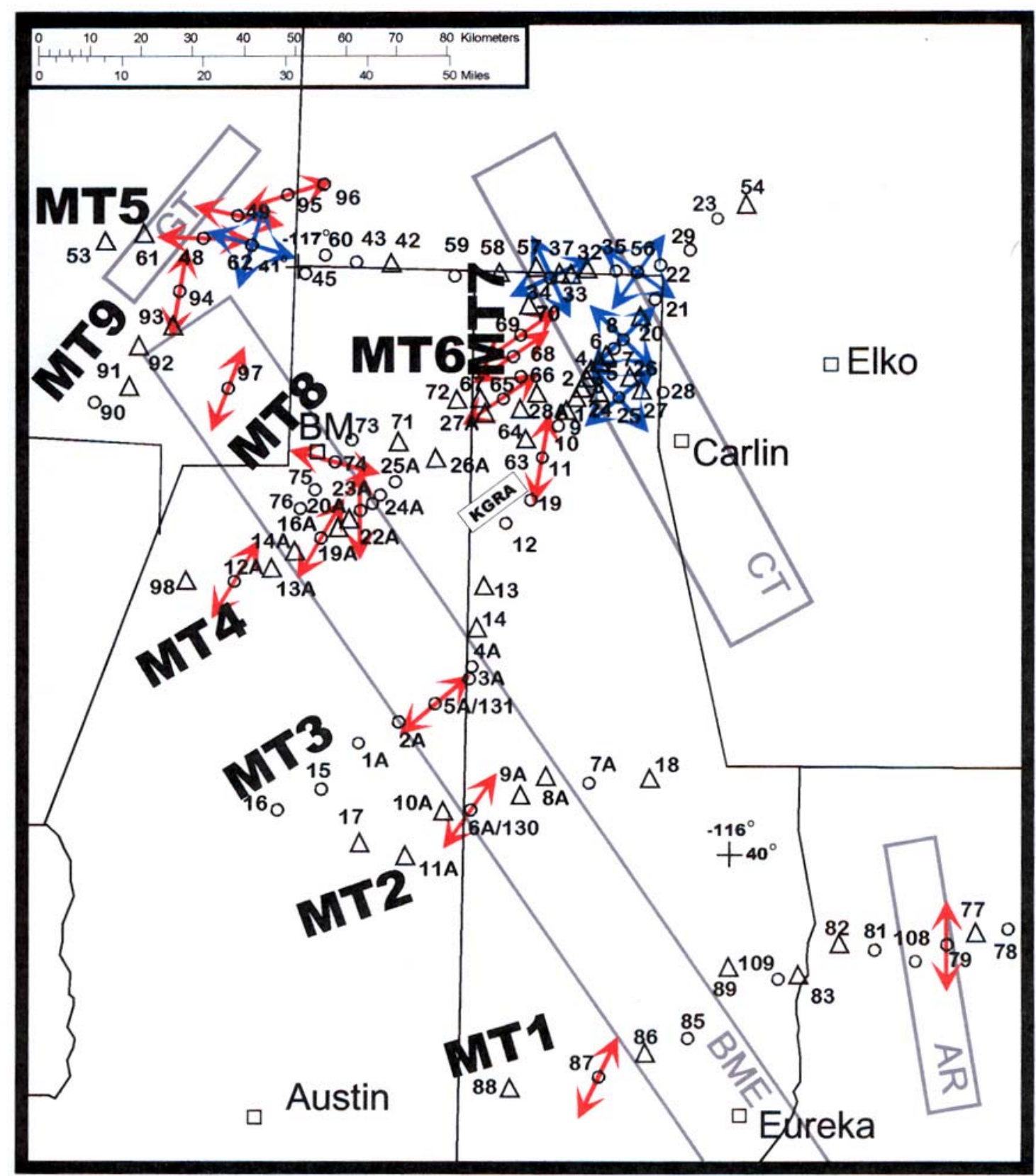

Figure 5. Deep conductor, electrical-strike directions for magnetotelluric (MT) profiles MT1 to MT9 (fig. 2). Arrow symbols show estimated 2-D strike directions for 2-D conductors at mid-crustal depths $(5-20 \mathrm{~km})$. Red arrows indicate strike directions constrained by vertical magnetic field. Blue arrows indicate strike directions that have $90^{\circ}$ ambiguity from impedance directions. Electrical strike resolution is about $\pm 10^{\circ}$. The gray lines represent generally accepted mineral belts in north-central Nevada (AR = Alligator Ridge district; BME = Battle Mountain-Eureka trend; $\mathrm{CT}=$ Carlin trend; $\mathrm{GT}=$ Getchell trend). Numbered MT stations are shown as open circles for MT data that are two-dimensional (2-D) in character and open triangles for data that have three-dimensional character in the lower frequencies. Thin black lines are county boundaries. KGRA is Beowawe Known Geothermal Resource Area. 
The crustal fault zones in the upper crust (1-5 km) show similar strike directions within the margin of error, $\pm 10^{\circ}$, as the deeper fault zones $(5-20 \mathrm{~km})$ except near stations 25,48 , and 49 (fig. 6). Near the Getchell trend, the shallow crustal fault zone strike directions of stations 48 and 49 are subparallel with the mountain range where this mineral belt is found. In the Carlin trend, the shallow crustal fault zone strike direction at station 25 is either north-south or east-west (as defined by an old MT station with $90^{\circ}$ ambiguity).

An interpretation of the deeper crustal fault zone strike directions appears in figure $\mathbf{7}$ (red and green ellipses) where the inferred strike directions for the ambiguous strikes are guided by the unambiguous strike directions of nearby conductors (fig. 5) and nearby modeled resistivity structure (figs. $\mathbf{3}$ and $\mathbf{4}$ ). The ellipses in figure $\mathbf{7}$ illustrate the conductor widths and lengths based on the horizontal electromagnetic response of the modeled 2-D conductors. The conductor widths are based on the resistivity model widths (figs. 3 and 4) corrected for projection between the profile direction and the conductor strike direction (fig. 5). The modeled 2-D conductor lengths, by definition, are infinite in a 2-D resistivity model. However, each conductor length represented in figure $\mathbf{7}$ is derived from the conductivity-thickness product (conductance) that is a function of the depth limit of the modeled conductor, which in turn is constrained by the lowest usable measured frequency that indicates a 2-D conductor. Some of the inferred crustal fault zones in figs. $\mathbf{3}$ and $\mathbf{4}$ are not shown to penetrate as deep as other crustal fault zones because nearby 3-D conductors did not provide a resistivity contrast to resolve how deep the 2-D conductor penetrated the crust. The assumption is that the same principle that applies to how deep a crustal fault zone is resolved also applies to the minimum resolvable length of a crustal fault zone because the electromagnetic response of a conductor is a function of 3-D space. In order to resolve the maximum length of crustal fault zones adequate, nearby MT station coverage is needed. The only inferred crustal fault zones that are subparallel to the major trends (green ellipses in fig. 7) are located in the Carlin trend, Getchell trend, and Alligator Ridge district. All other inferred crustal fault zones (red ellipses) in figure 7 are perpendicular or oblique to the trends.

Gravity and isotope data (Grauch and others, 2003) reveal northwest structural trends in basement rocks that reflect the deformational history of the region. The thick sections of deep-water clastic sediments in this area are prime candidates as source rocks for gold, with the Eocene Northeast Nevada Volcanic Field providing a major heat source to drive fluid circulation (Wannamaker and others, 2002). The proximity of several inferred crustal fault zones (fig. 7) to many major deposits (Goldstrike, Gold Quarry, Battle Mountain Complex, Getchell, Bootstrap, Marigold, Twin Creeks, and Meikle) suggests that subsurface fluid flow may have been significantly influenced by these fault zones. The correlation of the strikes of three inferred crustal fault zones with the strikes of the Carlin and Getchell trends and the Alligator Ridge district suggests they may have been the root fluid flow pathways that fed faults and fracture networks at shallower levels where gold precipitated in favorable host rocks. Some of the ore-controlling faults within the major trends are at large angles to the overall strike of the trends (Cline and others, 2005). Hence, dilation of oblique faults within trends due to translation, or dilation of faults between the trends at intersections with discordant crustal faults, may have influenced fluid movement. It is also possible that most of the crustal structures detected that do not correlate with ore-controlling fault zones are not representative of those that were open to fluid flow when the deposits formed. Rather, they may be structures that are open to fluid flow today. 


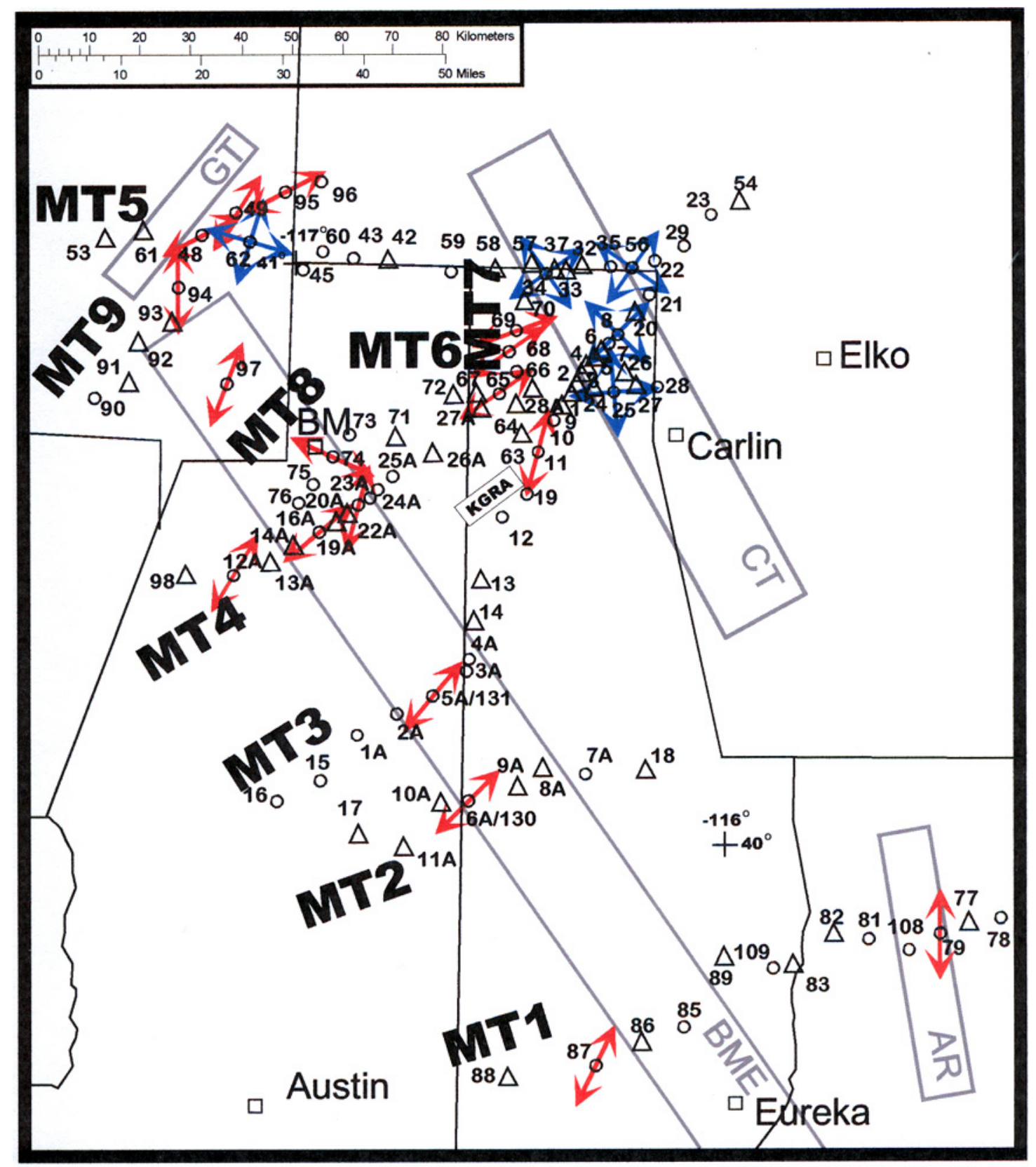

Figure 6. Shallow conductor, electrical-strike directions for magnetotelluric (MT) profiles MT1 to MT9 (fig. 2). Arrow symbols show estimated 2-D strike directions for 2-D conductors in the upper crust (1-5 km). Red arrows indicate strike directions constrained by vertical magnetic field. Blue arrows indicate strike directions that have $90^{\circ}$ ambiguity from impedance directions. Electrical strike resolution is about $\pm 10^{\circ}$. The gray lines represent generally accepted mineral belts in north-central Nevada $(A R=$ Alligator Ridge district; $\mathrm{BME}=$ Battle Mountain-Eureka trend; $\mathrm{CT}=$ Carlin trend; $\mathrm{GT}=$ Getchell trend). Numbered MT stations are shown as open circles for MT data that are two-dimensional (2-D) in character and open triangles for data that have three-dimensional character in the lower frequencies. Thin black lines are county boundaries. KGRA is Beowawe Known Geothermal Resource Area. 


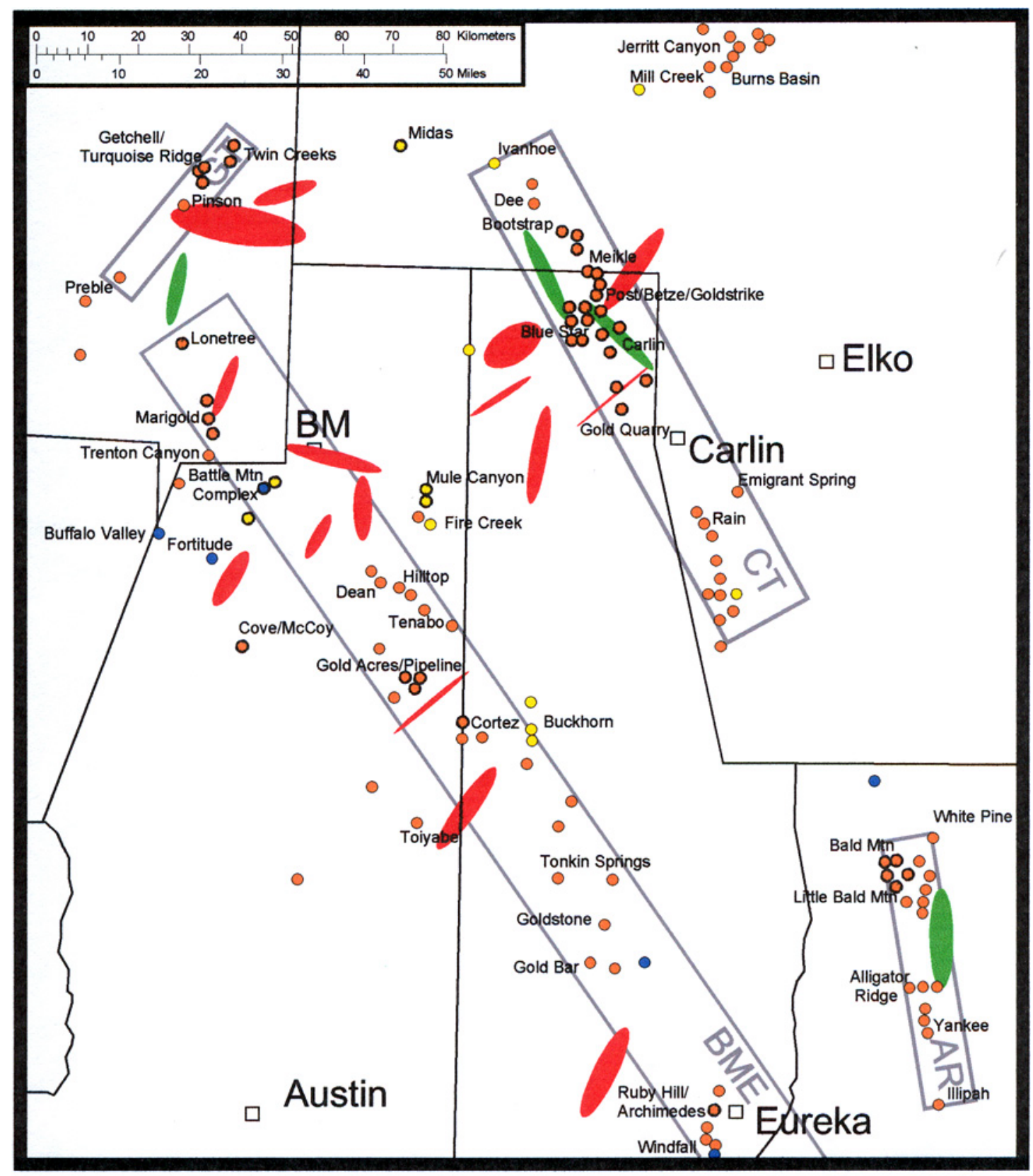

Figure 7. Deep crustal fault zone conductors in north-central Nevada. Ellipses illustrate estimated minimum widths and lengths based on deep sub-vertical 2-D conductors modeled (figs. 3 and 4) using magnetotelluric (MT) profiles MT1 to MT9 (fig. 2). Red ellipses illustrate crustal fault zones that are oblique to mineral belts, while green ellipses are for those that are subparallel. Orange-filled circles are disseminated gold deposits. Bold, orange-filled circles are major gold deposits. Blue-filled circles are pluton-related gold deposits. Yellow-filled circles are epithermal gold deposits. Gold deposit localities are from Brady (2005), Davis and Tingley (1999; 2005), Davis and others (2006), Driesner and Coyner (2006), and Wallace and others (2004). The gray lines represent generally accepted mineral belts in north-central Nevada $(A R=$ Alligator Ridge district; $\mathrm{BME}=$ Battle Mountain-Eureka trend; $\mathrm{CT}=$ Carlin trend; $\mathrm{GT}=$ Getchell trend). Thin black lines are county boundaries. 


\section{Conclusions}

Magnetotelluric data collected along nine profiles show deep resistivity structures beneath the Battle Mountain-Eureka (BME) and Carlin gold trends in north-central Nevada that appear consistent with tectonic breaks in the crust that possibly influenced preferred fluid flow pathways for hydrothermal fluids. Two-dimensional resistivity modeling of the magnetotelluric data generally show resistive (30 to $1,000 \mathrm{ohm}-\mathrm{m}$ ) crustal blocks broken by sub-vertical, two-dimensional conductors ( 1 to $30 \mathrm{ohm}-\mathrm{m}$ ) that are indicative of large-scale crustal fault zones. These inferred regional fault zones trend predominately northeast-southwest, but also north-south and northwest-southeast, and extend to mid-crustal depths (5-20 km). Some gold deposits along these linear trends possibly were controlled by deep regional crustal fault systems that intersected them.

The interpreted structure from these profiles provides constraints for future geologic interpretations of the genesis of gold deposits in the area of these mineral trends. The deep regional resistivity structure across the Carlin and BME trends may have direct implications for large gold resources in northeastern Nevada. The resistivity variations at mid-crustal levels reveal fault/fracture zones that may have influenced deformation in upper crustal rocks that localized fluid flow and precipitation of gold ores in the Northern Nevada Gold Province.

\section{Acknowledgements}

Data collection, processing, resistivity modeling, and preliminary interpretations in this project were supported by the U.S. Geological Survey Mineral Resources Program under the Nevada Gold and Metallogeny of the Great Basin projects. We are grateful for access to survey sites by the Bureau of Land Management, the Humboldt National Forest Service, Barrick Gold, Hecla Mining, Kennecott Minerals, Newmont Mining, and Placer Dome Mining.

\section{References Cited}

Arehart, G.B., Foland, K.A., Naeser, C.W., and Kesler, S.E., $1993,{ }^{40} \mathrm{Ar} /{ }^{39} \mathrm{Ar}, \mathrm{K} / \mathrm{Ar}$, and fission track geochronology of sediment-hosted disseminated gold deposits at Post-Betze, Carlin Trend, northeastern Nevada: Economic Geology, v. 88, no. 3, p. 622-646.

Bendat, J.S., and Piersol, A.G., 1971, Random Data-Analysis and Measurement Procedures: New York, Wiley Interscience, 407 p.

Brady, M., 2005, Nevada gold - 1993 to 2004: Nevada Bureau of Mines and Geology Open File Report 05-3, 178 p.

Cline, J.S., Hofstra, A.H., Muntean, J.L., Tosdal, R.M., and Hickey, K.A., 2005, Carlin-type gold deposits in Nevada-critical geologic characteristics and viable models, in Hedenquist, J.W., Thompson, J.F.H., Goldfarb, R.J., and Richards, J.P., eds.: Economic Geology, 100th Anniversary Volume, p. 451-484.

Davis, D.A., and Tingley, J.V., 1999, Gold and silver resources in Nevada: Nevada Bureau of Mines and Geology, Map 120, 1:1,000,000-scale plate. 
Davis, D.A., and Tingley, J.V., 2005, Precious metals deposits of Nevada, in Rhoden, H.N., Steininger, R.C., and Vikre, P.G., eds., Window to the World, Symposium Proceedings: Geological Society of Nevada, Reno, v. 1, p. 179-186.

Davis, D.A., Tingley, J.V., and Muntean, J.L., 2006, Gold and silver resources in Nevada: Nevada Bureau of Mines and Geology, map 149, 1:1,000,000-scale plate.

Deszcz-Pan, M., Rodriguez, B.D., Doucette, J.P., Godbout, M., Williams, J.M., Sawyer, D.A., Stone, B.D., and Grauch, V.J.S., 2000, Digital airborne time domain electromagnetic data from surveys over Cochiti Pueblo, Rio Puerco, and Rio Rancho, New Mexico: U.S. Geological Survey Open-File Report 00-502 (CD-ROM).

Dobrin, M.D., and Savit, C.H., 1988, Introduction to Geophysical Prospecting (4th ed.): New York, McGraw-Hill, 867 p.

Driesner, D. and Coyner, A., 2006, Major mines of Nevada 2005, Mineral industries in Nevada's economy: Nevada Bureau of Mines and Geology Special Publication P-17, 28 p.

Eberhart-Phillips, D., Stanley, W.D., Rodriguez, B.D., and Lutter, W.J., 1995, Surface seismic and electrical methods to detect fluids related to faulting: Journal of Geophysical Research, v. 100, no. B7, p. 12,919-12,936.

Grauch, V.J.S., Jachens, R.C., and Blakely, R.J., 1995, Evidence for a basement feature related to the Cortez disseminated gold trend and implications for regional exploration in Nevada: Economic Geology, v. 90, p. 203-207.

Grauch, V.J.S., Rodriguez, B.D., and Wooden, J.L., 2003, Geophysical and isotopic constraints on crustal structure related to mineral trends in north-central Nevada and implications for tectonic history: Economic Geology and the Bulletin of the Society of Economic Geologists, v. 98, no. 2, p. 269-286.

Hofstra, A.H., and Cline, J.S., 2000, Characteristics and models for Carlin-type gold deposits, Chapter 5: in Hagemann, S.G., and Brown, P.E., eds., Gold In 2000, Reviews in Economic Geology, v. 13, p. 163-220.

Ilchik, R.P., and Barton, M.D., 1997, An amagmatic origin of Carlin-type gold deposits: Economic Geology, v. 92, no. 3, p. 269-288.

John, D.A., Hofstra, A.H., and Theodore, T.G., 2003, A special issue devoted to gold deposits in northern Nevada-Part 1, Regional studies and epithermal deposits, Preface: Economic Geology, v. 98, p. 225-234.

Keller, G.V., 1987, Rock and mineral properties, in Nabighian, M.N., ed., Electromagnetic Methods in Applied Geophysics Theory: Tulsa, Oklahoma, Society of Exploration Geophysicists, v. 1, p. 13-51. 
Keller, G.V., 1989, Electrical properties, in Carmichael, R.S., ed., Practical handbook of physical properties of rocks and minerals: Boca Raton, Florida, CRC Press, p. 359-427.

Nelson, P.H., and Anderson, L.A., 1992, Physical properties of ash flow tuff from Yucca Mountain, Nevada: Journal of Geophysical Research, v. 97, no. B5, p. 6823-6841.

Palacky, G.J., 1987, Resistivity characteristics of geologic targets, in Nabighian, M.N., ed., Electromagnetic Methods in Applied Geophysics Theory: Tulsa, Okla., Society of Exploration Geophysicists, v. 1, p. 53-129.

Radtke, A.S., 1985, Geology of the Carlin gold deposit, Nevada: U.S. Geological Survey Professional Paper 1267, 124 p.

Ritter, O., Hoffmann-Rothe, A., Bedrosian, P.A., Weckmann, U., and Haak, V., 2005, Electrical conductivity images of active and fossil fault zones, in Bruhn, D. and Burlini, L., eds., High-strain zones; structure and physical properties: Geological Society Special Publications, v. 245, p. 165-186.

Rodriguez, B.D., and Williams, J.M., 2001, Deep regional resistivity structure across the Battle Mountain-Eureka and Carlin trends, north-central Nevada: U.S. Geological Survey Open-File Report 01-346, 165 p.

Rodriguez, B.D., and Williams J.M., 2002, Resistivity structure across the Humboldt River Basin, north-central Nevada: U.S. Geological Survey Open-File Report 02-39, 114 p.

Shawe, D.R., 1991, Structurally controlled gold trends imply large gold resources in Nevada, in Raines, G.L., Lisle, R.E., Schafe, R.W., and Wilkinson, W.H., eds., Geology and ore deposits of the Great Basin, Symposium Proceedings: Geological Society of Nevada, Reno, v. 1, p. 199-212.

Sillitoe, R.H., and Bonham, H.F., 1990, Sediment-hosted gold deposits; distal products of magmatic-hydrothermal systems: Geology, v. 18, no. 2, p. 157-161.

Struhsacker, E.M., Jones, E., and Green, S.M., 1996, Roadside geology and precious-metal mineralization along the I-80 corridor, Reno to Elko, Nevada, in Struhsacker, E.M., and Green, S.M., eds., Geology and ore deposits of the American Cordillera - Field Trip Guidebook Compendium: Geological Society of Nevada, Reno, Nevada, p. 3.

Tosdal, R.M., Wooden, J.L, and Kistler, R.W., 2000, Geometry of the Neoproterozoic continental break-up, and implications for location of Nevadan mineral belts, in Cluer, J.K., Price, J.G., Struhsacker, R.F., Hardyman, R.F., and Morris, C.L., eds., Geology and Ore Deposits 2000-The Great Basin and Beyond, Symposium Proceedings: Geological Society of Nevada, Reno, Nevada, v. 1, p. 451-466.

Vozoff, K., 1972, The magnetotelluric method in the exploration of sedimentary basins: Geophysics, v. 37, p. 98-141. 
Vozoff, K., 1991, The magnetotelluric method, in Nabighian, M.N., ed., Electromagnetic methods in applied geophysics: Tulsa, Oklahoma, Society of Exploration Geophysicists, v. 2, part B, p. 641-711.

Wallace, A.R., Ludington, S., Mihalasky, M.J., Peters, S.G., Theodore, T.G., Ponce, D.A., John, D.A., and Berger, B.R., 2004, Assessment of metallic mineral resources in the Humboldt River basin, northern Nevada: U.S. Geological Survey Bulletin 2218, 295 p.

Wannamaker, P.E., 1989, PW2DIS User Documentation - Finite element program for solution of magnetotelluric responses and sensitivities for two-dimensional earth resistivity structure: Earth Science Laboratory, University of Utah Research Institute, Salt Lake City, Utah, ESL-89043-TR, 50 p.

Wannamaker, P.E., and Doerner, W.M., 2002, Crustal structure of the Ruby Mountains and southern Carlin Trend region, Nevada, from magnetotelluric data: Ore Geology Reviews, v. 21 , p. $185-210$.

Wannamaker, P.E., Doerner, W.M., Stodt, J.A., Sodergen, T.L., and Rodriguez, B.D., 2002, Analysis of magnetotelluric profile data from the Ruby Mountains metamorphic core complex and southern Carlin Trend region, Nevada: U.S. Geological Survey Open-File Report 02-214, 50 p.

Wannamaker, P.E., Hohmann, G.W., and Ward, S.H., 1984, Magnetotelluric responses of three-dimensional bodies in layered earths: Geophysics, v. 49, no. 9, p. 1517-1533.

Williams, J.M., and Rodriguez, B.D., 2000, Deep electrical geophysical measurements across the Carlin trend, Nevada: U.S. Geological Survey Open-File Report 00-419, 141 p.

Williams, J.M., and Rodriguez, B.D., 2001a, Magnetotelluric data across the Battle Mountain-Eureka and Carlin trends, north of Eureka, Nevada: U.S. Geological Survey Open-File Report 01-168, 135 p.

Williams, J.M., and Rodriguez, B.D., 2001b, Magnetotelluric data across the Battle Mountain-Eureka and Carlin trends, near the 41st parallel, Nevada: U.S. Geological Survey Open-File Report 01-278, 127 p.

Williams, J.M., and Rodriguez, B.D., 2001c, Magnetotelluric data across Boulder Valley and the Humboldt River, Nevada: U.S. Geological Survey Open-File Report 01-279, 124 p.

Williams, J.M., and Rodriguez, B.D., 2001d, Magnetotelluric data across the Battle Mountain-Eureka trend in Pumpernickel Valley and Kelly Creek Basin, Nevada: U.S. Geological Survey Open-File Report 01-316, 94 p. 
Williams, J.M., and Rodriguez, B.D., 2005, Magnetotelluric survey to locate the Archean/Proterozoic suture zone in north central Elko County, Nevada: U.S. Geological Survey Open-File Report 2005-1255, 184 p.

Williams, J.M., Rodriguez, B.D., and Klein, D.P., 2001a, Magnetotelluric data across the Battle Mountain-Eureka and Carlin trends, north of Cortez, Nevada: U.S. Geological Survey Open-File Report 01-117, 154 p.

Williams, J.M., Rodriguez, B.D., and Klein, D.P., 2001b, Magnetotelluric data across the Battle Mountain-Eureka and Carlin trends, south of Cortez, Nevada: U.S. Geological Survey Open-File Report 01-118, 109 p.

Williams, J.M., Rodriguez, B.D., and Klein, D.P., 2001c, Magnetotelluric data across the Battle Mountain-Eureka and Carlin trends, near Battle Mountain, Nevada: U.S. Geological Survey Open-File Report 01-228, 205 p. 